FILOLOGIJA 66, Zagreb 2016.

UDK 811.21/.22:81'0(=214.58) http://doi.org/10.21857/y26kecvol9

Izvorni znanstveni članak Primljen 20.XI.2015.

Prihvaćen za tisak 25.I.2016.

\author{
Mislav Ježić \\ Katarina Katavić \\ Odsjek za indologiju i dalekoistočne studije \\ Filozofski fakultet Sveučilišta u Zagrebu \\ Ivana Lučića 3 \\ HR-10000 Zagreb \\ mjezic@ffzg.hr \\ kkatavic@ffzg.hr
}

\title{
SANSKRTSKI I PRAKRTSKI KORIJENI ROMSKOGA
}

Romski jezik predstavlja indijski, i to novoindoarijski jezik, koji se je proširio cijelom Europom, pa tako i Hrvatskom, i mnogim dijelovima svijeta. U radu se pokazuje kako romski, iako je posudio mnogo riječi iz dijelova svijeta kojima su njegovi govornici prolazili ili u njima živjeli, dakle farsizama, bizantinizama, romanizama, slavizama i dr., pa i neke gramatičke oblike, npr. član, ipak čuva temeljni gramatički ustroj indijskoga, i to novoindoarijskoga jezika, koji se može izvoditi iz staroindoarijskoga ustroja i njegovih oblika (vedskih i sanskrtskih), preko srednjoindoarijskih (prakrtskih), do potvrđenih romskih gramatičkih oblika i sustava koji oni čine. Pritom se moraju uzeti u obzir glasovni zakoni koji vrijede za srednjoindoarijske jezike, a potom prepoznati i neki posebni zakoni koji vrijede za romski. Vidi se da su glasovne mijene izazvale $\mathrm{u}$ romskome sličan preustroj sklonidbe kao u hindskome, ali da je glagolski sustav u romskome u osnovi očuvao ustroj sintetičkih oblika, kakav je imao staroindoarijski, dok se je taj ustroj u hindskome raspao pa je stvoren nov sustav analitičkih oblika vremena, vidova i načina. Pregled izabranih gramatičkih oblika u povijesno-poredbenome okviru sastavio je Mislav Ježić, a izbor leksičkih podudarnica priredila je Katarina Katavić. Taj izbor romskih riječi (poredanih alfabetskim redom za indijske jezike) zorno oslikava kako su se glasovni zakoni za srednjoindoarijske jezike, a potom i za novoindoarijske, i posebno romski, odrazili u oblicima romskih riječi, i kako omogućuju da se prave romske riječi po postanju (tadbhave) razlikuju od posuđenica, pa i onih teže prepoznatljivih koje se u novije vrijeme znadu posuditi iz indijskih 
jezika i posebno iz sanskrta. ${ }^{1}$

Romski jezik predstavlja indijski jezik, novoindoarijski jezik, koji se je proširio cijelom Europom, pa tako i Hrvatskom, i mnogim dijelovima svijeta. ${ }^{2} \mathrm{Na}$ toliku prostoru tijekom duga vremena stvorio se je niz njegovih narječja, koja čine proučavanje romskoga teško preglednim, ali i vrijednim truda.

Romska narječja danas se dijele na:

vlaška:

- gurbetsko (džambasko), lovarsko, kalderaško (Rumunjska...)

nevlaška:

- arlijsko i bugurdžijsko (Bugarska, Makedonija, Grčka, Srbija, Crna Gora, Bosna i Hercegovina),

- karpatska (Mađarska, Slovačka, Češka),

- baltičko-poljsko-sjevernoruska,

- sintska (Zapadna Europa)

Postoje i pararomski jezici u prostorima preko kojih su Romi došli u Europu, iranskima i sirijskima, i u prostorima do kojih su došli, u Španjolskoj i Velikoj Britaniji: tu su Romi često izgubili svoju gramatiku i zadržali samo dio svojega leksika. Tako je svoj romski jezik izgubio i dio onih Roma koji su do Hrvatske došli iz Rumunjske, a govore varijantom rumunjskoga: to su Bajaši (Međimurje...).

Oko 47\% Roma danas živi u Jugoistočnoj Europi (na "Balkanu"), oko $60 \%$ onih koji su sačuvali svoj jezik.

U svojem su rječniku Romi sačuvali tragove svojega puta od Indije, preko Irana pa Byzantija do europskih krajeva u koje su došli. To se može oslikati razmjerno jednostavno imenima brojeva u romskome: ${ }^{3}$

${ }^{1} \mathrm{U}$ ovome radu morat ćemo $\mathrm{u}$ primjerima uglavnom zanemariti raznolikost među romskim dijalektima, npr. nepalatalizirajućim (lovarski, sintski) i palatalizirajućim dijalektima (arlijski, gurbetski, kalderaški), kao i onima koji čuvaju s (lovarski, istočnogurbetski, dijelom kalderaški i arlijski) i onima koji ga mijenjaju u $h$ (zapadnogurbetski, sintski). Prednost ćemo uglavnom davati konzervativnijim (bolje sačuvanim) oblicima.

${ }^{2}$ Rad je nastao na temelju izlaganja na skupu u HAZU povodom Svjetskoga dana romskoga jezika, 4. studenoga 2015.

${ }^{3} \mathrm{U}$ transkripciji indoarijskih izraza (osim romskoga koji ima svoj latinički pravopis) slovo $c$ stoji za prednje tvrdonepčano $c$, a $j$ za prednje tvrdonepčano $đ$. (U romskim riječima slova stoje za glasove uglavnom kao u hrvatskome.) 
Mislav Ježić, Katarina Katavić: Sanskrtski i prakrtski korijeni romskoga FILOLOGIJA 66(2016), 19-34

\begin{tabular}{|c|c|}
\hline romski & \\
\hline ek, jekh & Skt. eka, hind. ek, perz. yek \\
\hline duj & Skt. dvau, hind. do \\
\hline trin & Skt. trīṇi, hind. tīn \\
\hline štar & Skt. catvāri, hind. cār \\
\hline pañci, pandž & $\begin{array}{l}\text { Skt. pañca, hind. pāñc, perz. } \\
\text { panj }\end{array}$ \\
\hline ŠOV & Skt. șakș, hind. chah \\
\hline hefta & Skt. sapta, hind. sāt, grč. $\dot{\varepsilon} \pi \tau \alpha$ \\
\hline oxto & 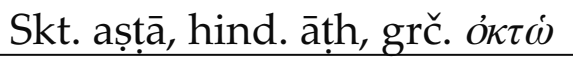 \\
\hline enja & Skt. nava, hind. no, grč. ćvvé $\alpha$ \\
\hline deš & Skt. daśa, hind. das, \\
\hline
\end{tabular}

Čini se da su Romi, kojima većina imena za brojeve ima indijsko podrijetlo, glasovne oblike za brojeve jedan i pet preuzeli u Iranu, a potom za brojeve sedam, osam i devet u Byzantiju. ${ }^{4}$ I inače romski ima dosta perzijskih i grčkih riječi. Velik dio europskih Roma živio je stoljećima u Rumunjskoj i susjednim slavenskim krajevima pa imaju u rječniku i dosta romanizama i slavizama. Danas obrazovani Romi rado unose u romski, kada im zatreba riječ, riječi iz indijskih jezika, osobito hindskoga, a među njima ima i dosta sanskrtizama.

U Europi sebe nazivaju raznim imenima: Romi, Sinti (npr. u Njemačkoj), Manuši (npr. u Francuskoj), Kale (npr. u Španjolskoj). Ime koje su u naše vrijeme izabrali kao opće, Rom, izvodi se od staroindoarijske posuđenice iz afroazijskoga jezika muṇ̣ā dōmba (potvrđeno u kašmirskoj pripovijednoj zbirci Kathāsaritsāgara pjesnika Somadeve iz 11. st.), koja označuje čovjeka iz (razmjeno niske) kaste svirača i pjevača (izvedeno iz riječi za bubanj): zato riječ i glasi u romskome $\underline{\operatorname{Rom}}$ (a ne Rom), s cerebralnim $\underline{r}$ od $d$, i s gubitkom nenaglašenoga sloga. Inače je riječ potvrđena u nizu novoindoarijskih jezika od Pañjāba do Rājasthāna i do Orisse te dardskih jezika na sjeverozapadu, a također $\mathrm{u}$ armenskome. ${ }^{5}$

Drugi su ih zvali Jeđupcima 'Egipćanima' (Gipsy, Gitano), kako su se sami znali predstavljati, ili Ciganima (byz. 9. st. Athinganoi, Azinganoi). To može imati veze s njihovim putom iz Prednje Azije u Europu ili u Afriku (i preko nje u doba kalifata npr. u Španjolsku). Prema tradiciji sačuvanoj u Firdūsīevoj Šāhnāmi, sasanidski je kralj Bahrām Gūr pozvao (u prvoj polovini 5. st.) tisuću indijskih glazbenika da zabavljaju glazbom i plesom puk

\footnotetext{
${ }^{4}$ Basham (izd. 1959.), 513.

${ }^{5}$ Turner (pretis. 1989.), 313-314, br. 5570.
} 
širom zemlje i dao im stoke i žita da se nasele, no oni su stoku i žito izjeli i nastavili su se seliti dalje. U Byzantiju se spominju oko 810. g. kao Athinganoi. Zatim su se proširili jugoistočnom Europom, a od početka 15. stoljeća stali su se seliti i u zapadnu Europu. Tada se spominju u Hildesheimu i Baselu. ${ }^{6}$ Danas su velika europska nacionalna manjina bez posebne domovine. A ima ih i u drugim dijelovima svijeta kojima su prolazili, a i onima u koje su se potom preselili, kao u Sjedinjenim Američkim Državama. Gotovo svugdje su ostajali izdvojeni od ostalih i međusobno povezani, slično srodnoj indijskoj kasti doma. Prihvaćali su kulturne utjecaje i religiju zemalja u kojima žive, ali su dijelom sačuvali jezik i način života.

No tek u 17. stoljeću se je naslutilo, a potkraj 18. stoljeća ustanovljeno je da im je jezik indijskoga podrijetla (Johann Christian Christoph Rüdiger 1782., Heinrich Moritz Gottlieb Grellmann 1787.), i to još prije nego je objavljena prva sanskrtska gramatika u Europi (Filip Vesdin 1790., 1804.), i to na osnovi sličnosti s hindskim jezikom. A sredinom je 19. stoljeća Franc Miklošič argumentirano dokazivao da su Romi morali doći s krajnjega sjeverozapada Indije po jezičnim osobinama.

Kako se može znati da je romski (sa svim svojim narječjima i govorima) indoarijski jezik? I izvodi li se iz staroindoarijskoga (vedskoga, sanskrta) i srednjoindoarijskih jezika?

To se dade prepoznati po nizu riječi koje su dovoljno slične indoarijskima, kao što je manuš 'čovjek', kan 'uho', nakh 'nos', yakh 'oko', kalo 'crn', lolo 'crven' itd. No to bi mogle biti leksičke posuđenice (ili tragovi nekadašnjega jezika), kao što je to dio brojeva (iako to nije vjerojatno npr. za dijelove lica) - kada jezik ne bi imao i gramatičku strukturu novoindoarijskih jezika.

Indijski jezici koji pripadaju indoeuropskoj jezičnoj porodici zovu se u znanosti indoarijskima da bi se razlikovali od drugih indijskih jezika koji pripadaju dravidskoj, austroazijskoj ili tibetoburmanskoj jezičnoj porodici. Indoarijska je potporodica indoeuropskih jezika izuzetna po tome što joj je, kao i romanskim jezicima, potvrđen i poznat prajezik. To je staroindoarijski, vedski i, u kasnijem standardiziranome i pojednostavljenome obliku, sanskrt.

Iz staroindoarijskoga postupno su nastali srednjoindoarijski jezici, prakrti, nizom glasovnih promjena koje su onda pokrenule morfološke i sintaktičke promjene i nastanak novih jezika. Iz prakrta su pak nastali novoindoarijski jezici.

Neke od glavnih glasovnih promjena pri nastanku prakrta bile su:

\footnotetext{
${ }^{6}$ Basham (izd. 1959.), 512-515.
} 
1. gubitak slogotvornih $r$ i $l(r$ prelazi u $a, i,(u)$; na sjeverozapadu u $r i$, $r u,(i))$.

2. monoftongizacija dvoglasa ai i au.

3. svođenje triju staroindoarijskih sibilanata ś, ș i s na jedan, najčešće $s$, osim u sjeverozapadnim narječjima.

4. veliko pojednostavljavanje i ujednačavanje suglasničkih skupina: one u prakrtima ne mogu imati više od dvaju suglasnika, a i ti se moraju posve asimilirati po zvučnosti, mjestu i načinu izgovora te postaju geminate (dopuštena je razlika samo po aspiriranosti ili po nazalnosti) ili se moraju razbiti anaptyktičkim samoglasnicima: jyotsnā (mjesečina) postaje joṇhā ili joisinna, dharma postaje dhamma, akși postaje akkhi itd.

5. slogovi se ritimički ujednačuju tako da mogu imati samo 1 ili 2 more (mātrāa): stoga je u zatvorenu slogu moguć samo kratak samoglasnik, a ako se samoglasnik ostvaruje kao dug, ne mogu mu slijediti dva suglasnika, nego najviše jedan: mogući su nizovi glasova: $\breve{V}, \overline{\mathrm{V}}, \breve{\mathrm{V} C C}, \mathrm{~V} N C$ i V̄C (nemoguće je $\overline{\mathrm{V} C C}$ ili $\overline{\mathrm{V}} \mathrm{NC}$ ).

6. postupno slabe pojedinačni suglasnici, bezzvučni postaju zvučni, otjesnačuju se (frikativiziraju) i u posljednjoj fazi i gube, od aspirata često ostaje samo aspiracija $h$.

7. slabi i sibilant $\mathrm{u}$ aspiratu $h$.

8. $y$ često palatalizira zubnike, a i sam prelazi u $d$ (transl. $j$ ).

9. velika su ograničenja glasova koji mogu stajati na kraju riječi: u načelu samoglasnici i poslijesamoglasni nazal anusvāra ṃ. (U prijelazu na novoindoarijske jezike može doći do novih glasovnih promjena ako se stanu gubiti završni samoglasnici.)

U načelu samo su oni riječi i jezični oblici novoindoarijski, koji pretpostavljaju te srednjoindoarijske glasovne promjene kroz koje su prošli staroindoarijski glasovi i glasovne skupine. Stoga, ako se u romskome javljaju riječi kao čakra 'kotač' ili čitra 'slika', 'nacrt', one neće biti novoindoarijske ni izvorno romske, nego u novije vrijeme posuđeni sanskrtizmi (tatsame). A riječi kao kan 'uho', nakh 'nos', yakh 'oko', arakhavel 'čuva', ašunel 'sluša' itd. bit će novoindoarijske i romske (tadbhave) jer su prošle takve glasovne promjene:

sti. karṇa > pkt. kanna / kāna > H. kān / R. kan

sti. $a k s ̦ i>$ pkt. $a k k h i>$ H. âkh / R. yakh

Novoindoarijski se značaj očituje i u gramatičkome ustroju romskoga. Osobne zamjenice tu glase: 

FILOLOGIJA 66(2016), 19-34

\begin{tabular}{|l|l|l|l|}
\hline staroindoarijski & prakrt & hindski & romski \\
\hline aham / mām 'ja' & ahā / mā & maĩ & me \\
\hline tvam 'ti' & tuvā... tuhū & tū & tu \\
\hline vayam / asmān 'mi' & asme / amhe & ham & amen \\
\hline yūyam /yuṣmān 'vi' & tumhe & tum & tumen \\
\hline
\end{tabular}

U sklonidbi imenica (i zamjenica) raspao se sustav staroindoarijskih osam padeža. Prvo se je stao gubiti dativ i zamjenjivati genitivom, zatim se ablativ suobličio instrumentalu, a na kraju su se u novoindoarijskim jezicima ostali razlikovati samo još izravni i kosi padež, a kosomu su se padežu stali dodavati prethodni složenični dočetci ili posljelozi (postpozicije) da bi se razlikovala padežna značenja. U tome je ishodu romski vrlo blizak hindskomu.

\begin{tabular}{|c|c|c|c|}
\hline \multicolumn{2}{|l|}{ hindski - jednina } & \multicolumn{2}{|l|}{ romski } \\
\hline N. gã̃v 'selo' & bakrā 'jarac' & gav 'selo' & bakro 'ovan' \\
\hline Acc. gã $v(k o)$ & bakrā / bakre ko & gaves & bakres \\
\hline I. gã̃v se & bakre se & gaves-sa & bakres-sa \\
\hline D. gã̃v ko & bakre ko & gaves-ke & bakres-ke \\
\hline Abl. gã̃v se & bakre se & gaves-tar & bakres-tar \\
\hline G. gã̃̄ $v$ kā / kî̀ / ke & bakre kā / kī / ke & $\begin{array}{l}\text { gaves-ko } \\
\text { /-ki /-ke }\end{array}$ & $\begin{array}{l}\text { bakres-ko /-ki } \\
\text { /-ke }\end{array}$ \\
\hline L. gã̃v mẽ / par & bakre par & gaves-te & bakres-te \\
\hline
\end{tabular}

\begin{tabular}{|l|l|l|l|}
\hline \multicolumn{2}{|l|}{ hindski - množina } & romski \\
\hline n. gã̃v & bakre & gava & bakra \\
\hline acc. gã̃v / gã̃võ ko & bakre / bakrõ ko & gaven & bakren \\
\hline i. gã̃võ se & bakrõ se & gaven-ca & bakren-ca \\
\hline d. gã̃võ ko & bakrõ ko & gaven-ge & bakren-ge \\
\hline abl. gã̃võ se & bakrõ se & gaven-dar & bakren-dar \\
\hline g. gã̃võ kã / kī / ke & bakrõ kā / kī / ke & $\begin{array}{l}\text { gaven-go } \\
\text { /-gi /-ge }\end{array}$ & $\begin{array}{l}\text { bakren-go /-gi } \\
\text { /-ge }\end{array}$ \\
\hline L. gãã mẽ / par & bakrõ mẽ / par & gaven-de & bakren-de \\
\hline
\end{tabular}

U navedenim primjerima imenice H. gẫv i R. gav te H. bakrā i R. bakro ishod su podudarna razvoja preko prakrta:

sti. grāma > pkt. gāma > gām ' > H. gẫ̂ / R. gav

sti. barkara 'jare, janje' > (dem.) barkaraka / varkaraka > pkt *bakkaraga $>$ pkt. *bakaraa > H. bakrā / R. bakro 
Posljelozi se izvode iz dočetnih dijelova složenica: H. se 'sa, pomoću; iz / od' izvodi se iz sti. sahita 'praćen', 'združen', H. par 'na' iz sti. para 'gornji', a H. mẽ 'u' iz madhye 'u sredini', 'među'.

Osobito su zanimljivi primjeri genitiva: H. $k \bar{a} / k \bar{\imath} / k e$ i R. - ko /-ki /-ke (-go /-gi /-ge) koji se izvode iz dočetka sti. krta 'učinjen, uzrokovan od' > pkt. kata, f. kațì, pl. kate > pkt. kaa, f. kā̄, pl. kae > kā, f. kì, pl. ke.

Tu pratimo dugotrajni usporedni niz mijena u prakrtima i novoindoarijskim jezicima, hindskome i romskome. Ujedno vidimo da se staroindoarijska sklonidba potpuno preustrojila, urušavajući se preko srednjoindoarijske, osobito posljednje faze - apabhramsśe, do ponovnoga ustrojavanja u novoindoarijskim jezicima, koje polazi od složenica / kompozicije i završava u novim analitičkim oblicima padeža (pred posljelozima ne stoji više osnova, nego kosi padežni oblik).

No da ne pomislimo da se romski razvijao u izolaciji od jezika s kojima su Romi dolazili u doticaj, možemo navesti da je u »balkanskome jezičnome savezu " primio član koji indoarijski jezici nemaju, pa mu oblici bakro 'ovan', bakri 'ovca' i bakre 'ovce' (mn.) s članom glase: o bakro, i bakri i e bakre - sve se vrlo harmonično spojilo tako da se i ne vidi da član koji se mijenja slično kao i imenica koju prati nije indijskoga, nego grčkoga podrijetla: ó, $\eta$, ó, koji se čitaju $o, i$, e.

Kod glagola imamo dijelom usporedan razvoj, ali romski je manje urušio stari sustav sprezidbe negoli hindski u kojem više nema starih sintetičkih (staroindoarijskih) glagolskih oblika, nego se glavna vremena u indikativu izriču analitički pomoću a) glagolskoga participa prezenta aktivnoga (radnoga i negotovoga: prijelaznoga ili neprijelaznoga, ovisno o glagolu) i pomoćnoga glagola ili b) glagolskoga participa perfekta (tj. gotovoga) pasivnoga (zapravo, neprijelaznoga). če:

Tako se u hindskome negotovo sadašnje (zapr. svagdašnje) vrijeme izri-

mẽ kar(a)tā /-tī hũ otpr. 'ja sam čineći /-ća', 'I do / make' (tr.) mẽ jātā /-tī hũ otpr. 'ja sam hodeći /-ća', 'I go / walk' (intr.)

A sadašnje nesvršeno (trajno) vrijeme:

mẽ kar(a) rahā /-ī hũ otpr. 'ja ostajem čineći /-ća, radeći /-ća', 'I am doing / making'

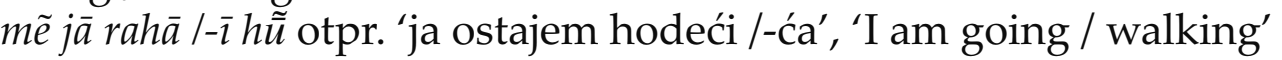

Gotov se pak vid u sadašnjosti izriče:

mẽ ne $(k \bar{a} m(a))$ kiyā hai (agentiv / ergativ) otpr. 'od mene je (posao) učinjen, urađen' 


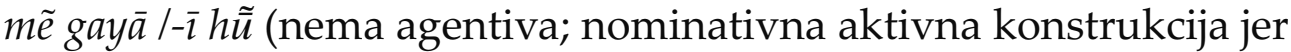
je glagol neprijelazan) 'otišao /-la sam'

Prošlo se negotovo vrijeme izriče tako da se umjesto prezenta pomoćnoga glagola honā 'biti' (on se izvodi iz sti. bhü, bhavati 'biva', 'jest') uz particip prezenta stavlja oblik koji se shvaća kao prošlo vrijeme pomoćnoga glagola / kopule thi / thi / the (koji se mijenja po rodu i broju, kao posljelog $k \bar{a}$ u sklonidbi; a izvodi se iz sti. sthita 'stajao /-la'):

$m \tilde{e}(k \bar{a} m(a)) k a r(a) t \bar{a} /-t \bar{\imath}$ thā / thī. 'ja sam činio /-la / radio /-la'

$m \tilde{e}$ jātā /-tī thāa thì otpr. 'ja sam išao /-šla'

$\mathrm{U}$ prošlom se gotovome vremenu rabi isti oblik kopule uz particip perfekta (gotovi particip):

mẽ ne (kām(a)) kiyā thāa (agentiv / ergativ) otpr. 'od mene je (posao) bio (bijaše) učinjen'

$m \tilde{e}$ gaya $/-\bar{\imath}$ tha / thì (nema agentiva; nominativ, aktiv) 'bio /-la sam (bijah) otišao /-la'

Taj je sustav u hindskome vrlo bogat i razrađen, ali novostvoren.

$\mathrm{U}$ romskome nije tako. $\mathrm{U}$ romskome su dva glavna vremena prezent $\mathrm{i}$ preterit. Niz se drugih glagolskih oblika izvodi iz njih dometcima. A ona izgledaju ovako:

Prezent

\begin{tabular}{|l|l|l|l|}
\hline kerel 'radi, čini', sg. & pl. & džal 'ide', sg. & pl. \\
\hline 1. kerav & keras & džav & džas \\
\hline 2. keres & keren & džas & džan \\
\hline 3. kerel & keren & džal & džan \\
\hline
\end{tabular}

Preterit

\begin{tabular}{|l|l|l|l|}
\hline kerel 'radi, čini', sg. & pl. & džal 'ide', sg. & pl. \\
\hline kerdem & kerdam & gelum & gelam \\
\hline kerdan & kerden & gelan & gelen \\
\hline kerdas & kerde & gelo & gele \\
\hline
\end{tabular}

U romskome prezent nije analitičko, nego još uvijek jest sintetičko vrijeme. Ne samo da tako izgleda, nego ako bolje promotrimo glasovne zakone, prepoznat ćemo da su oblici glagolskih lica uvelike sačuvani kroz glasovne mijene.

Ako pogledamo ove romske riječi koje su nastale od staroindoarijskih:

sti. bhūmi ‘zemlja > R. phuv

sti. dhüma 'dim'> R. thuv

sti. nāman 'ime' > R. anav 
sti. bhrātr 'brat' > R. phral

sti. devatā 'božanstvo' > R. devel

sti. śata 'sto' > R. šel / šol

uočit ćemo da se u romskome gubi nenaglašeni samoglasnik na kraju riječi, a $m$ prelazi u $v$. Isto tako u takvu položaju $t$ prelazi u $l$. (Usput rečeno, refleks $l$ za sti. $t$ povezuje romski s dardskim jezicima na sjeverozapadu indijskoga potkontinenta.)

Stoga možemo povezati romsku sprezidbu sa staroindoarijskom, barem nastavke $\mathrm{u}$ prezentu:

\begin{tabular}{|l|l|}
\hline staroindoarijski & romski \\
\hline 1.1.sg. karomi yāmi & kerav džav \\
\hline 2.1.sg. karoši yāsi & keres džas \\
\hline 3.1.sg. karoti yāti & kerel džal \\
\hline 3.1. mn. kurvanti yanti & keren džan \\
\hline
\end{tabular}

Dodatno se može pripomenuti da su i korijeni glagola sti. kr, R. ker i H. kar podudarni, kao i korijeni glagola sti. yāa, R. $d \check{z} a-(1)$ i H. jāa-(tā) (v. gore) te korijen glagola sti. gam i oblici R. aorista gelo i H. participa gotovoga gayā. Tako se oblici $d \check{z} a v$ i yāmi mogu izvesti sve još iz indoeuropskoga oblika * $\mathrm{yeH}_{2} \mathrm{mi}$, a oblici gayā i gelo od indeuropskoga ${ }^{*} \mathrm{~g}^{\mathrm{W}} \mathrm{m}$-to! No i u hindskome i u romskome ti se korijeni dopunjuju gradeći (jedinstvenu) mješovitu glagolsku paradigmu.

Od prezenta i preterita kao temeljnih oblika u romskome se tvori više izvedenih oblika: npr. dometkom -as od prezentskih se oblika tvori imperfekt, a od preteritskih pluskvamperfekt i sl.

Starinu čuva i romski particip prezenta na -ando-, -indo-, kao prastando(j) 'trčeći, -a, -e' od gl. prastal (stind. pra-sthā-), kerindo(j) 'radeći', 'čineći, -a, -e' od gl. kerel (stind. kar-/kr-), rovindoj 'plačući, -a, -e' od gl. rovel itd. (stind. rud-), gdje podudarnost sa stind. dometkom -ant/-at, a prakrtskim tematiziranim -aṃta-, ne samo da postoji, nego je još i prepoznatljiva.

Malo je manje površno prepoznatljiv, ali ništo manje podudaran i particip neprijelazni gotovi (ppp.): kerdo 'učinjen' od gl. kerel (stind. kar-/kr-, pkt. karoti, ppp. krta, pkt. kata), ćhindo 'rezan' od gl. ćhindel (stind. i pkt. chindati, ppp. chinna), dikh-lo 'viđen' od gl. dikhel (stind. drśs-, pkt. dikkhati, ppp. drșța, pkt. dițtha), kamlo 'ljubljen' od gl. kamel (stind. i pkt. kam-, ppp. kānta, pkt. kamta), pa i phandito 'vezan', 'zatvoren' od gl. phandel (stind. bandh- , pkt. bandh, ppp. baddha) i rodito 'tražen' od gl. rodel (stind. dhūndh-, pkt. dhumdholai). Sve su to participi nastali od staroindijskih i prakrtskih participa na $-t a$, koje iza osnova na $n, r, l$ u romskome postaje - $d o$, a iza osnova 
na $m, s, s, k$, g ili kh postaje -lo (opet $l$ od $t$ u romskome, kao u 3. 1. sg.).; ${ }^{7}$ oni pak na -ito odražuju staroindijske i prakrtske participe na -ita.

Zanimljivo je da ti participi nisu naprosto tadbhave (tj. kao participi izvedeni iz prakrtskih i staroindoarijskih participa), nego analogijom novouspostavljene tvorbe od romskih osnova i eufonijskih varijanata participskoga dometka.

Analogno su se nanovo uspostavili iz istih staroindoarijskih i prakrtskih participa i hindski participi negotovi: $k a r(a) t \bar{a} /-t \bar{\imath} /-t e$ i jāta /-tī /-te, ali participi gotovi tih glagola kiyā i gayā jesu tadbhave, izravno izvodive iz pkt. kida(-ka), kiya(-a) i gada(-ka), gaya(-a). No većina drugih kao dekh(a)tā

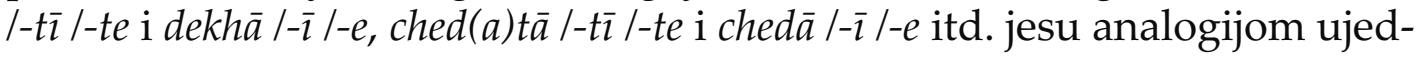
načeni novouspostavljeni oblici iz (naslijeđenih) osnova i dometaka.

To bi mogao biti izbor gramatičkih primjera za ovu priliku, koje je uzeo u zadatak izabrati Mislav Ježić za ilustraciju toga kako možemo s izvjesnošću znati da je romski novoindoarijski jezik, srodan s hindskime, i to takav u kojem se i mnogi gramatički oblici mogu izvoditi iz staroindoarijskoga (vedskoga i sanskrta) preko prakrta, kao što se mogu i mnoge riječi sačuvane $\mathrm{u}$ romskome.

A evo izbora riječi koje mogu oprimjeriti leksičke podudarnosti između romskoga i hindskoga, odnosno prakrta i staroindoarijskoga (vedskoga, sanskrta), a koje je skupila kolegica Katarina Katavić: ${ }^{8}$

\begin{tabular}{|c|c|c|c|}
\hline romski & hindski & prakrt & staroindoarijski \\
\hline abser (prilika) & avasar & avasara & avasara \\
\hline akhor (orah) & akharot & akkhoḑa & akșoța \\
\hline anav (ime) & nām & nāma & nāman \\
\hline ando $(\mathrm{u})$ & andar & aṃto & antar \\
\hline angali (zagrljaj) & ãkwār & aṃkavāli & an̉kapāli \\
\hline angar (ugljen) & añgār & aṃgāra & an்gāra \\
\hline angle (najprije) & agalā & -aggala- & agra \\
\hline anro (jaje) & anḍ̄ā & amda & anda \\
\hline arakhavel (čuvati) & rakhanā & ārakkha- & $\sqrt{ }{ }^{R A K S}, \bar{a}-$ rakșati ${ }^{*}$ \\
\hline asal (smijati se) & haṃsanā & hassai & $\sqrt{H A S}$, hasati \\
\hline asva (suza) & āmssū & amsu & aśru \\
\hline ašunel (čuti) & sunanā & sunedi & لŚRU, śṛ̣oti \\
\hline
\end{tabular}

\footnotetext{
${ }^{7}$ Courtiade (2008.), 393 i 401.

8 Pri tome je za provjeru etimologija dragocjen bio rječnik Sir R. L. Turnera (1966./1989.)
} 


\begin{tabular}{|c|c|c|c|}
\hline romski & hindski & prakrt & staroindoarijski \\
\hline baj (rukav) & bāmh & bãhu & bāhu \\
\hline bakri (ovca) & bakrī & barkara-ka & barkara \\
\hline bal (dlaka) & bāl & vāla & vāla \\
\hline baro (velik) & baụā & vaḍ̣a & vadra \\
\hline bićinel (prodati) & becanā & vikkināti & vikriṇāti \\
\hline bokh (glad) & bhūkh & bhukkhã & bubhukșāā \\
\hline $\mathrm{b}(\mathrm{e}) \mathrm{rš}$ (godina) & varș & (vassa) & varșa \\
\hline but (mnogo) & bahut & bahutta & bahutva \\
\hline čačo (istinit) & sāc & sacca & satya \\
\hline čiriklo (ptica) & cidiyā & cidiga & cataka \\
\hline čor (kradlijivac) & cor & cora & cora \\
\hline čorel (ukrasti) & coranā & coreti & $\sqrt{ }$ CUR, corayati \\
\hline čuči (dojka) & cuci & cuci & cuccu, cucci \\
\hline čumi-del (poljubiti) & cumanā & cucuya- & لCUMB, cumbati \\
\hline čhib (jezik) & jïbh & jibbhā & jihvā \\
\hline čhuri (nož) & churā & churā, churī & kșurā, kṣurī \\
\hline ćhinel (rezati) & chinānā & chiṃdai & $\sqrt{ } \mathrm{CHIND}$, chindati \\
\hline dand (zub) & dānt & damta & dantaka \\
\hline dar (strah) & dar & - & dara \\
\hline darel (bojati se) & ḍaranā & dāraṃta & 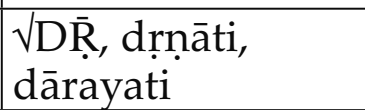 \\
\hline das (ne-Rom) & dās & dāsa & dāsa \\
\hline del (dati) & denā & deї & ل $\mathrm{D} \overline{\mathrm{A}}$, dadāti \\
\hline Devel (Bog) & dev & (devayā) & devatā \\
\hline dikhel (vidjeti) & dekhanā & dakkhaï & VDRŚ, dṛkșati \\
\hline doš (grijeh) & doș & (dosa) & doșa \\
\hline dukh (bol) & dukh & dukkha & duhkha \\
\hline dur (dalek) & dūr & dūra & dūra \\
\hline di (dah) & $\mathrm{j} \overline{1}$ & jīva & jīva \\
\hline džal (otići) & jānā & jāï & $\sqrt{Y} \bar{A}$, yāti \\
\hline džangavel (buditi) & jāganā & jaggāvaï & jāgrati \\
\hline džanel (znati) & jānanā & jānaï & 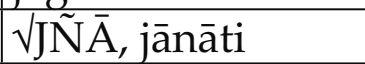 \\
\hline dživdipen (život) & jīvan & jīvaï & jīvana \\
\hline džuv (uš) & jūm & jūã & yūka \\
\hline
\end{tabular}




\begin{tabular}{|c|c|c|c|}
\hline romski & hindski & prakrt & staroindoarijski \\
\hline gav (selo) & gāṃv & gāma & grāma \\
\hline ginel/đinel (brojati) & ginanā & ganeï & $\sqrt{\text { GAN, ganayati }}$ \\
\hline xal (jesti) & khānā & - & $\sqrt{\text { GHAS, ghasati }}$ \\
\hline irat/erat (noć) & rāt & rāttīi & rātri \\
\hline jag (vatra) & āg & aggi & agni \\
\hline jakh (oko) & āṃkh & akkhi & akși \\
\hline kalo (crn) & kālā & kāla & kāla \\
\hline kamel (voljeti) & kām & kāma & kāma \\
\hline kan (uho) & kān & kaṇna & karṇa \\
\hline kinel (kupiti) & $--^{* *}$ & vi-kkiṇāti & لVRĪ, krīṇāti \\
\hline kon (tko) & kaun & - & kah punar \\
\hline khelel (igrati se) & khelanā & khelaï & $\sqrt{\text { KHED, kheḍati }}$ \\
\hline kher (kuća) & ghar & ghara & gṛha \\
\hline ladž (sram) & lajj & lajjā & lajjā \\
\hline lel (uzeti) & lenā & laheï & $\sqrt{\mathrm{LABH}}$, labhati \\
\hline lil (pisati) & likhanā & lihia & لVIKH, likhita \\
\hline lolo (crven) & lāl & lohia & lohita \\
\hline ma (ne) & mat & mā & mā \\
\hline mačho (riba) & machalī & maccha & matsya \\
\hline makh (muha) & makkhī & makkhiā & makșikā \\
\hline mangel (željeti) & māṃganā & maggaï & $\sqrt{ } \mathrm{MĀ} R \mathrm{R}$, mārgati \\
\hline manuš (čovjek) & manuṣ & mānuṣa & mānuṣa \\
\hline mas (meso) & māṃs & māsa & māṃsa \\
\hline melalo (prljav) & mailā & - & malina \\
\hline merel (umrijeti) & maranā & maraï & $\sqrt{\mathrm{MR}, \text { mriyate }}$ \\
\hline muj (usta) & mūṃh & muha & mukha \\
\hline muso (miš) & mūṣ & mūsì & mūṣa \\
\hline muter (mokraća) & mūt & mūtta & mūtra \\
\hline na (ne) & na & na & na \\
\hline najol (kupati se) & nahānā & nhāna & $\sqrt{ }$ SNĀ, snāti \\
\hline nakh (nos) & nāk & nakka & nāsika \\
\hline pani (voda) & pānī & pāṇīa & pānīya \\
\hline paše (blizu) & pās & passa, pāsa & pārśve \\
\hline patri(n) (list) & patra & (patta) & patra \\
\hline -pe(n) (-stvo) & -pan & -tpa- (?) & -tvam (?) \\
\hline pe (po) & par/pe & upparim & ${ }^{*}$ uppari (?) \\
\hline pekel, pećel (peći) & pakānā & pacaï & $\sqrt{ } \mathrm{PAC}$, pacati \\
\hline
\end{tabular}




\begin{tabular}{|c|c|c|c|}
\hline romski & hindski & prakrt & staroindoarijski \\
\hline piro (noga) & pair & - & *padara (?) \\
\hline purano (star) & purānā & purāna & purāna \\
\hline pustik (knjiga) & pustak & - & pustaka \\
\hline phak (krilo) & paks & pakkha & pakșa \\
\hline pharo (težak) & bhārī & bhāra & bhāra \\
\hline phen (sestra) & behen & bahin̄ī & bhaginī \\
\hline phirel (lutati) & phiranā & phiraï & phirati \\
\hline phov (obrva) & bhaũ(h) & bhumā & bhrū(-vā?) \\
\hline phral (brat) & bhāī & bhāā, bhāī & bhrātṛ \\
\hline phuro (star) & būḍā & buddha & vrddha>vuddha \\
\hline phuv (zemlja) & bhūmi & bhūmi & bhūmi \\
\hline rašaj (svećenik) & rși & SZPkt rașaya & rși \\
\hline rat $(\mathrm{krv})$ & rakt (skt.) & ratta & rakta \\
\hline rovel (plakati) & ronā & rovaï & $\sqrt{R U D}$, rodati \\
\hline saro (sve) & sab & sāra, sabba & sarva \\
\hline sap (zmija) & sã̃p & sappa & sarpa \\
\hline sasto (zdrav) & svasth (skt.) & sattha & svastha \\
\hline šašuj (svekrva) & sāsū & sassū & śvaśrū \\
\hline sikel, sikavel (učiti) & sīkhanā & $\begin{array}{l}\text { sikkhati (Caus. } \\
\text { sikhāpeti) }\end{array}$ & لŚ́IKȘ, śikșati \\
\hline sovel (spavati) & sonā & $\begin{array}{l}\text { svapati, su- } \\
\text { pati }\end{array}$ & $\sqrt{\text { SVAP, svapiti }}$ \\
\hline sungal (njušiti) & sūnighanā & sunghaï & śrnikhati \\
\hline šero (glava) & sar/sir & sira & śiras \\
\hline šing (rog) & sīng & singa & śṛnga \\
\hline šol/šel (sto) & so & sata & śata \\
\hline šukarel (sušiti) & sūkhanā & sukkha- & VSUȘ, sușkati \\
\hline truš (žeđ) & trụṣāā & - & trụyā \\
\hline thagar (kralj) & thākur & - & thakkura \\
\hline than (mjesto) & sthān & thāṇa & sthāna \\
\hline thovel (prati) & dhonā & dhovaï & لVHŪ, dhūnoti \\
\hline thud (mlijeko) & dūdh & duddha & dugdha \\
\hline thuv (dim) & dhuã & dhūma & dhūma \\
\hline učo (visok) & ūṃcā & ucca & ucca \\
\hline upral (gore) & ūpar & uppariṃ & $\begin{array}{l}\text { uppari (ut-para- } \\
\text { tah) }\end{array}$ \\
\hline
\end{tabular}


Mislav Ježić, Katarina Katavić: Sanskrtski i prakrtski korijeni romskoga FILOLOGIJA 66(2016), 19-34

\begin{tabular}{|c|c|c|c|}
\hline romski & hindski & prakrt & staroindoarijski \\
\hline ural (letjeti) & uḍanā & uḍdeï & $\begin{array}{l}\text { uḍ } \sqrt{ } \overline{\mathrm{D}} \overline{\mathrm{I}} \text {, uḍdayate, } \\
\text { uḍḍ̂iyate }\end{array}$ \\
\hline $\begin{array}{l}\text { vakerel, vaćarel (go- } \\
\text { voriti) }\end{array}$ & vāk & vācā & vāc/vāk, vaktum \\
\hline vaj (ili) & vā & vā & vā \\
\hline var (put, puta) & bār & vāra & vāra \\
\hline vast (ruka) & hāth & hattha & hasta \\
\hline
\end{tabular}

* umjesto infinitiva naveden je glagolski korijen i glagol u 3. 1. jd. prez. akt.

* * hindski glagol kharìdanā perzijskog je porijekla

Razmatrajući ustroj romskoga prvo smo pogledali na neke crte gramatičkoga ustroja, a potom na izbor iz leksika. Jasno smo mogli uočiti ne samo da je romski srodan i podudaran s drugim novoindoarijskim jezicima, nego da gdjekada, na primjer u sustavu sprezidbe, čuva i veću starinu od, recimo, hindskoga. Romski ktomu oprimjeruje novoindoarijski jezik koji nasljeđuje osobine što su se pojavljivale negdje od Aśokina vremena $u$ sjeverozapadnim narječjima prakrta (refleks glasa $r$ kao ra, ru (rašaj, truš), a ne samo $a, i$, itd.), a potom $u$ novoindoarijskim i dardskim jezicima i govorima (refleks $t$ kao $l$ po otpadanju završnoga samoglasnika itd.), a i preko njih još jasno pokazuje kako i koliko je ukorijenjen u prakrtima i, osobito, staroindoarijskome. Ako se uzmu u obzir svi glasovni zakoni za srednjoindoarijske jezike, a potom i za novoindoarijske, i posebno romski, koji su se odrazili u oblicima romskih riječi, oni omogućuju da se prave romske riječi po postanju (tadbhave) jasno razlikuju od posuđenica, a time i da se prepozna očuvani izvorni romski leksik.

Zbog svega toga možemo reći da romski s gledišta jezikoslovlja predstavlja dragocjeno jezično nasljeđe. Stoga se može govornicima njegovima reći ga vrijedi očuvati, njegovati i razvijati.

Naravno, dodatno kulturološko blago predstavljaju i one sastavnice romskoga u kojima se je odrazio i doticaj Roma sa svim kulturama čijim su područjima prolazili, a sred kojih su ipak očuvali svoju posebnu jezičnu baštinu. Stoga je romski pun farsizama, bizantinizama, romanizama, slavizama i europeizama. No nije neprirodno, nego, naprotiv, primjereno i skladno kada romski jezikoslovci zagledaju i u indijske jezike, a preko njih i u sanskrt, tražeći nove riječi za nove civilizacijske pojmove. Oni, budu li to umjeli, na to imaju jednako pravo kao francuski, engleski ili ruski na obogaćivanje iz latinskih, grčkih i staroslovjenskih leksičkih izvora. No to, naravno, nije više povijesno- ni poredbeno-jezikoslovna, nego standardološka tema. 


\section{Literatura}

Basham, Arthur Llewellyn. 1954., 1959. The Wonder that Was India, New York: Grove Press.

Bloch, Jules. 1933. L'Indo-aryen du Véda aux temps modernes, Paris. Engl. prošireno izdanje (1965.), Indo-Aryan from the Vedas to Modern Times, prev. Alfred Master, Paris: Librairie d'Amerique et d'Orient Adrien-Maisonneuve.

Bubenik, Vit. 1996. The Structure and Development of Middle Indo-Aryan Dialects, Delhi: Motilal Banarsidass.

Cardona, George i Dhanesh Jain. 2003. The Indo-Aryan Languages, LondonNew York: Routledge.

Courthiade, Marcel. 2008. Pregled morfoloških promjena u romskom jeziku, u: Kajtazi, Veljko (2008.), Romano-kroacijako thaj Kroacijako-romano alvari. Romsko-hrvatski i Hrvatsko-romski rječnik, Zagreb: Odjel za orijentalistiku HFD-a i Kali Sara, 389-404.

Demir, Ljatif i Nevsija Durmiš. 2012. Gramatika romskoga jezika, Zagreb: Kali Sara.

Kajtazi, Veljko. 2008. Romano-kroacijako thaj Kroacijako-romano alvari. Romsko-hrvatski i Hrvatsko-romski rječnik, Zagreb: Odjel za orijentalistiku HFD-a i Kali Sara.

McGregor, Ronald Stuart. 1993., 1997. The Oxford Hindi-English Dictionary, Delhi: Oxford University Press.

Lapov, Zoran. 2008. Riječ redaktora, u: Kajtazi, Veljko. 2008. Romano-kroacijako thaj Kroacijako-romano alvari. Romsko-hrvatski i Hrvatsko-romski rječnik, Zagreb: Odjel za orijentalistiku HFD-a i Kali Sara, 13-19.

Mayrhofer, Manfred. 1951. Handbuch des Pāli, sv. I-II, Heidelberg: Carl Winter.

Rašić, Nikola. 2008. Uvod u gramatičku strukturu romskih govora u Hrvatskoj, u: Kajtazi, Veljko. 2008. Romano-kroacijako thaj Kroacijako-romano alvari. Romsko-hrvatski i Hrvatsko-romski rječnik, Zagreb: Odjel za orijentalistiku HFD-a i Kali Sara, 345-388.

Tahirović-Sijerčić, Hedina. 2000. Bosansko-romski i Romsko-bosanski rječnik. Bosnaki-Rromani thaj Rromani Bosnaki alavari, Mostar: Federalno ministarstvo obrazovanja i nauke.

Turner, Ralph L. 1966., pretis. 1989. A Comparative Dictionary of the IndoAryan Languages, London-New York-Toronto: Oxford University Press.

Uhlik, Rade. 1983. Srpsko-hrvatsko-romsko-engleski rečnik. Romengo alavari, Sarajevo: Svjetlost. 


\title{
Sanskrit and Prakrit Roots of the Romany Language
}

\begin{abstract}
The Romany language is a New Indo-Aryan language which has spread through the whole of Europe, including Croatia, and through many other parts of the world. The paper shows that the Romany language betrays many traces of contacts with the languages of those regions in which its speakers lived or passed through. It contains many loanwords from Persian, Byzantine Greek, Romance and Slavic languages, etc. It also betrays some traces of foreign influences, like articles, in its grammar. The Romany language preserves, however, the basic grammatical structure of an Indian, New Indo-Aryan, language. Its grammatical forms can be traced through the Middle IndoAryan languages (Prakrits) to the Old Indo-Aryan language (Vedic, Sanskrit). In recognizing forms, as in recognizing the origin of words, the phonetic laws of change of Old Indo-Aryan through Middle Indo-Aryan to New Indo-Aryan, and specifically to the Romany language, must be taken into account. It can be clearly shown that declension underwent a parallel change in Romany as it did in Hindi, but that the verbal system in Romany basically preserved the synthetic verbal forms inherited from the Old Indo-Aryan language. In this respect, Romany preserved the verbal system better than Hindi, where it collapsed, and a new system of analitical formation of tenses, aspects and moods had to be created. While Mislav Ježić prepared the survey of grammatical forms in the historical and comparative framework, Katarina Katavić prepared a selection of lexical items derived from Old and Middle Indo-Aryan vocabulary. This list of words clearly illustrates how phonetic laws for Middle Indo-Aryan languages, and then specifically for Romany, produced the current forms of genuine Romany words (tadbhava), and how they can be distinguished from loanwords, including those which were borrowed from Indian languages, and especially from Sanskrit, in modern times.
\end{abstract}

Ključne riječi: sanskrtski, prakrtski, romski

Key words: Sanskrit, Prakrit, Romany language 